\title{
AUSTRALIAN PROTEACEAE: NEW TAXA AND NOTLS
}

\author{
D.J. McGillivray
}

(Received September 1973)

\section{ABSTRACT}

\begin{abstract}
McGillivay, D. J. (National Herbarium of New' South Wales, Royal Botanic Gardens, Sydney, Australia) 1975. Australian Proteaceae: New Taxa and Notes, Telopea 1 (1): 19-32, Plates I-V. Grevillea coriacen (Queensland) p. 19, G. cyranostigma (Q.) p. 20, G. glossadenia (Q.) p. $21, G$. johnsonii (New South Wales) p. 22, G. rivularis (N.S.W.) p. 23, and Isopogon mnoraifolius (N.S.W.) p. 31 are described. The following new combinations are made:- Grevillea acanthifolia ssp. stenomera (F. Muell. ex Benth.) p. 23, Grevillea speciosa (Knight) [syn. G. punicea R. Br.] p. 24, Hakea eyreana (S. Moore) [syn.
[S. $H$. divaricata L. Johnson] p. 30 , and Isopogon prostratus nom. nov. (syn. I. anemonifolius var. tenuifolius F. Muell. ex Benth.) p. 32. The names Grevillea agrifolia A. Cunn. ex $\mathrm{R}$. Br. and $G$. angulata $\mathrm{R}$. Br. are typified to avoid future confusion, and $G$. agrifolia var. major Ewart et Rees is synonymized under $G$. agrifolia; the relationship between $G$. asplenifolia Knight and $G$. longifolia $\mathrm{R}$. $\mathrm{Br}$. is discussed and clarified; the name $G$. biformis Meisn. is maintained to be correct for the species named $G$. stenocarpa F. Muell. ex Benth.; the reason for the mistaken inclusion of $G$. cirsifolia Meisn. in the floras of New South Wales and Queensland is uncovered; the major differences between $G$. heliosperma $\mathrm{R}$. Br. and $G$. decurrens Ewart are outlined; the differences between $G$. oleoides Sieber ex Schultes et Schultes f. and $G$. dimorpha F. Muell. are briefly mentioned, and a lectotype for $G$. seymowiae Sweet ex Meisn, is selected; G. glabella $\mathrm{R}$. Br. is reinstated as a species; the nomenclature of $G$. glabrata (Lindl.) Meisn. and $G$. cuneata (Endl.) Druce, nomen inval., is discussed; $G$. brachyclada W.V. Fitzg. is synonymized under $G$, inconspicua Diels; $G$. heteroneura W.V. Fitzg., $G$, ceratophylla R. Br. and G. refracta var, ceratophylla (R. Br.) Benth. are synonymized under $G$, parallela Knight; the name $G$. pityophylla F. Muell. replaces $G$. blackallii C.A. Gardn., synon. nov.; the rediscovery of $G$. rosmarinifolia $A$. Cunn. is reported; the close relationship between $G$. shiressii Blakely and $G$. singuliflora $F$. Muell. is mentioned; a note is given about the possible extinction of Hakea pulvinifera L. Johnson; and Petrophile pulchella (Schrad.) $\mathrm{R}$. $\mathrm{Br}$. is re-affirmed as a correct name.
\end{abstract}

All the specimens cited have been seen unless otherwise indicated.

Comments, criticisms and suggestions relating to this paper or to other aspects of the taxonomy of Australian Proteaceae would be welcomed.

\section{Grevillea coriacea $D$. McGillivray, sp. nov.}

Aff. $G$. parallelae Knight sed foliis coriacioribus inflorescentiis racemosis vel parce ramosis, floribus paucioribus majoribus differt.

Holotype: QUeEnsLAnd: 58 miles $[93 \mathrm{~km}$ ] from Coen towards Moreton Telegraph Station, C.H. Gittins 1820, 7.1968 (located in the National Herbarium of New South Wales, Sydney).

Small slender tree or tall single-stemmed shrub c. 4-15 metres high, and up to c. $25 \mathrm{~cm}$ diameter; branchlets rounded, ash-grey, pubescent to hoary. Leaves subsessile more or less linear, $12-30 \mathrm{~cm}$ long, $4-10 \mathrm{~mm}$ wide, leaf base tapering gradually to a short pulvinate petiole; leaf apex acute to obtusemucronate sometimes chewed or curled; leaf margin sharply recurved to revolute; upper surface glabrous with obscure venation, lower surface sericeous with 
prominent mid-vein and intramarginal veins; lateral veins acutely angled usually few and inconspicuous; texture coriaceous; leaves drying to a light yellowishgreen or light brown. Inflorescence terminal on short branchlets, 20-60-flowered, 8-15 cm long with up to 3 branches per inflorescence; rhachis glabrous or nearly so. Flowers glaucous and glabrous on outer surface; pedicels $6-10 \mathrm{~mm}$ long; perianth c. $20 \mathrm{~mm}$ long, broadest at the base, tapering to a recurved subglobular limb $3 \mathrm{~mm}$ diameter, lower part of tepals papillose to pilose on inner surface; torus conspicuously oblique c. $3 \mathrm{~mm}$ long; gland inconspicuous, U-shaped, enclosed within the torus; pistil 30-40 $\mathrm{mm}$ long, glabrous; stipe $2.0-2.5 \mathrm{~mm}$ long; ovary globular $1.5 \mathrm{~mm}$ diameter; style slightly thickened near apex; pollen presenter* c. $2 \mathrm{~mm}$ long, lateral, oblong in outline, broadly conical; stigma distally off-centre. Fruits ellipsoid, $22-28 \mathrm{~mm}$ long, $18-24 \mathrm{~mm}$ wide, thickness equal to c. $2 / 3$ width; pericarp c. $1.5 \mathrm{~mm}$ thick along suture, up to c. $4 \mathrm{~mm}$ maximum thickness on the sides; seeds ovate in outline, smooth, peripterous; "wing" of seed up to c. $5 \mathrm{~mm}$ wide. Flowering period: June to August.

Distribution: The species is apparently restricted to woodland and savammah woodland of the eastern part of the Cook district of northern Queensland. It is recorded from near Petford to the south, and northwards to the region between Coen and Moreton on the Cape York Peninsula. In some situations it occurs with Grevillea parallela Knight but usually it is found in drier less fertile areas.

SElECTED SPECIMENS: Cook District (north to south): Jeannie River-Howick River $14^{\circ} 40^{\prime}$ S., $144^{\circ} 45^{\prime}$ E., altitude 40 metres, Hyland $6285,26.7 .1972$ (NSW); 4 miles [6 $\mathrm{km}$ ] from Laura towards Mt Molloy, Gittins 1882, 8.1968 (NSW); Cooktown road, c. 40 miles $[65 \mathrm{~km}$ ] from Cooktown, Gittins 559, 6.1962 (NSW, BRI); Mt. Carbine Bates 5.11 .1966 (K); 9 miles $[14 \mathrm{~km}] \mathrm{S}$. of Mt Molloy, Trapnell 149, 7.6.1960 (BRI); Mt Mulligan, Flecker 19.2.1934 (BRI); near Mareeba, Springs Road off Dimbulah Road, altitude $1200 \mathrm{ft}[360$ metres], Bates 14.8 .1966 (K, NSW); c. 5 miles [8 km] E. of Mareeba, Thorne 22767 \& Tracey, 10.8 .1959 (RSA, NSW): 5.7 miles [9.1 km] from Petford towards Irvinebank, Bates (K).

Grevillea coriacea is closely related to G. parallela Knight (syn. G. polysiachya $\mathrm{R}$. Br.) but differs in its slender habit, more coriaceous leaves and sparingly branched or unbranched inflorescences with fewer and larger flowers. The flowering period for $G$. coriacea is June to August, whereas, in the same region, $G$. parallela commences flowering in September.

I am grateful to Dr R.D. Melville (Kew) for permitting me to examine his notes on this species, and to refer to his correspondence from Mr L.K. Bates of Mareeba. Mr Bates made many useful notes as well as collections of both $G$. parallela and $G$. coriacea which he recognized as distinct species.

Grevillea cyranostigma $D$. McGillivray, sp. nov.

Aff. G. juniperinae R. Br, sed foliis oblongis latioribus obtusis, floribus minoribus fere glabris, pistillis usque $2 \mathrm{~cm}$ longis differt.

Holotype: QueEnsLand: Leichhardt District: Mt Playfair, Mrs. Biddulph, 1890-1895 (top right of sheet MEL 46751 located in the National Herbarium of Victoria, Melbourne).

Shrub, branchlets rounded, sericeous. Leaves oblong, convex with a cuneate, shortly petiolate base and an obtuse mucronulate apex; leaf margin recurved; upper surface glabrous with a slender raised mid-vein and c. 5 acutely-angled,

* Pollen presenter:- the swollen end of the style on which, at anthesis, pollen is deposited and loosely held. In Grevillea the stigma is usually located at or near the centre of the pollen presenter. The term, which has been used by Guthrie \& Salter in the treatment of Proteaceae for the Flora of the Cape Peninsula by Adamson and Salter (1950), seems likely to become widely accepted. 
lateral veins per side; lower surface sericeous, rusty, mid-vein conspicuous, lateral veins usually obscure. Inflorescence terminal on short axillary branches, recurved, 6-12-flowered, slightly shorter than the adjoining leaves; rhachis sericeous; pedicels filiform, c. $\frac{1}{3}$ length of perianth, with few appressed slender hairs, glabrescent; torus slightly oblique; perianth almost glabrous outside with few basal and terminal hairs, villous inside on lower half except for glabrous area between torus and ovary; limb ovate, pointed, only slightly bent (not recurved); gland horseshoe-shaped, sparingly dentate; pistil glabrous, slightly exceeding perianth in length; ovary stipitate, equal in length to stipe; pollen presenter lateral, obovate with a conspicuous, subterminal, umbonate stigma. Fruit narrowly ovoid, slightly viscid. (Description based on the Holotype).

Distribution: The species is recorded from "Mt Playfair" Station and Moolyamba near the Carnarvon Range in the Leichhardt district of Queensland.

SPECIMENS EXamined: QueEnSland: Leichhardt District: Toowoomba (cultivated from seed collected at Moolyamba, near Carnarvon Range), Hockings 8.9.1964 (BRI 060179); "Mt Playfair" Station, Biddulph 30, 8.1956 (BRI).

Grevillea cyranostigma is closely related to $G$. juniperina but differs from it in its broader, oblong, obtuse leaves and smaller almost glabrous flowers. This species has already been mentioned by D. Hockings in Austral. Pl. 6: 39 (1970).

The pollen presenter of this new species and the head of Cyrano de Bergerac show a particular similarity in their profiles.

\section{Grevillea glossadenia D. McGillivray, sp. nov.}

Aff. $G$, decorae Domin sed partibus omnibus minoribus, venis foliorum lateralibus sub angulo $20-25^{\circ}$ prodeuntibus differt.

Holotype: Queensland: Cook District: near Bakerville $17^{\circ} 25^{\prime}$ S., $145^{\circ} 15^{\prime}$ E., shrub $2 \mathrm{~m}$ tall, low open forest, Hyland 5927, 17.iii.1972. (Located in the National Herbarium of New South Wales, Sydney). IsOTYPE: QRS.

Shrub 1-2 metres high, branchlets angular to rounded, sericeous, reddish= brown to grey. Leaves elliptical to obovate, c. $5-12 \mathrm{~cm}$ long, $2-3.5 \mathrm{~cm}$ wide, shortly petiolate; leaf base narrowly cuneate; leaf apex obtuse with a point to sub-acute; leaf margin irregularly recurved and undulate; upper surface sericeous, red-brown on young leaves to ash-grey; venation on upper surface conspicuous and prominent, lateral veins at $20-25^{\circ}$ to mid-vein, intra-marginal veins 2 , situated within $4 \mathrm{~mm}$ of the margin and $1.5-3 \mathrm{~mm}$ apart, some reticulate venation evident; venation of lower surface becoming indistinct on older leaves. Inflorescence terminal 5-12 flowered; rhachis $1-1.5 \mathrm{~mm}$ long, subsericeous, reddish; floral bracts caducous (not seen); pedicels sericeous, reddish, 5-8 $\mathrm{mm}$ long; torus very oblique to lateral c. $5 \mathrm{~mm}$ long; perianth recurved, sericeous, reddish outside, pubescent inside to just below level of ovary, broad at the base, abruptly tapering to a depressed globose limb; longer pair of tepals c. $13 \mathrm{~mm}$ long; gland linguiform $2 \mathrm{~mm}$ long, apex recurved 4-toothed; pistil c. $27 \mathrm{~mm}$ long, slightly flattened dorsiventrally, villous to sericeous, with fewer hairs towards stigma; stipe (from base of gland) $6 \mathrm{~mm}$ long; ovary $1.5 \mathrm{~mm}$ long; pollen presenter lateral $2.2 \mathrm{~mm}$ long, $1.8 \mathrm{~mm}$ wide, obovate in outline, very broadly conical; stigma distally off-centre. Fruits obliquely obovoid, $14 \mathrm{~mm}$ long, $8 \mathrm{~mm}$ wide, pericarp rather uniform in thickness c. $1 \mathrm{~mm}$ thick; seeds oblong to narrowly ovate in outline, $7-8 \mathrm{~mm}$ long, $3.5 \mathrm{~mm}$ wide, $2 \mathrm{~mm}$ thick, finely papillose on the outer surface, fringed on the inner surface by a narrow border $0.5 \mathrm{~mm}$ wide. (Description based on the Holotype).

Distribution: Apparently restricted to the Cook District of Queensland, being recorded from Irvinebank, and near Bakerville. 
Specimens Examined: Cook District: about 11 miles $[17.5 \mathrm{~km}] \mathrm{W}$. of Herberton, on ridge of decomposed granite, shrub with several, slender, obliquely ascending stems to $5 \mathrm{ft}[1.5 \mathrm{~m}]$, leaves bright green above, white tomentose beneath, young leaves rusty brown, perianth deep yellow, style orange red, Everist $5153,24.5 .1952$ (BRI); Irvinebank $17^{\circ} 26^{\prime}$ lat., $145^{\circ} 12^{\prime}$ long., on shallow soils on roadside, shrub to $1 \mathrm{~m}$, flowers red, Pedley 1920 , 24.11.1965 (BRI).

\section{Grevillea johnsonii D. McGillivray, sp. nov.}

Aff. $G$. longistylae Hook. sed pinnis augustioribus c. 0.9-1.4 $\mathrm{mm}$ latis, inflorescentiis brevibus, rachidibus $1-3 \mathrm{~cm}$ longis, stylis sericeis differt.

Holotype: New South Wales: Kerrabee Mtn, Kerrabee, 1.1 miles $[1.8 \mathrm{~km}]$ E. of Cox's Gap railway tunnel, and c. 150 yds [135 metres] N. of railway formation (east side of slight gully), spreading shrub $10 \mathrm{ft}$ [3 metres], rare on south-facing sheltered slope below sandstone cliffs, L.A.S. Johnson NSW 33695, 16.x.1955. (Located in the National Herbarium of New South Wales, Sydney).

Slender to spreading shrub 2-4.5 metres high, young stems rounded, pubescent, sometimes hoary. Leaves pinnatisect, c. $12-25 \mathrm{~cm}$ long; pinnae 5-10 per leaf usually slightly less than $1 \mathrm{~mm}$ wide (probably never more than $1.5 \mathrm{~mm}$ wide) slender, linear, closely aligned and nearly parallel to rhachis, commonly finely pubescent, lower pinnae sometimes bipartite. Inflorescence terminal on short axillary branches, sometimes paniculate, 8-16-flowered (up to 50 -flowered in panicles); rhachis $1-3 \mathrm{~cm}$ long with dense rusty indumentum; floral bracts, present only with very young buds, rhomboid to ovate-acuminate, c. $2 \mathrm{~mm}$ long, with rusty hairs on dorsal surface; pedicels 10-15 mm long, slender, sericeous, ferrugineous; perianth 22-25 $\mathrm{mm}$ long, almost parallel-sided below curve, with appressed reddish hairs outside, sericeous towards the torus, pubescent inside with short white hairs un to the level of the top of the ovary; limb angular, subglobose, c. $3 \mathrm{~mm}$ long; torus very oblique almost lateral; gland long-U-shaped, canaliculate with a basal pouch, c. $2.5 \mathrm{~mm}$ long; pistil $32-38$ $\mathrm{mm}$ long, sericeous to about the middle of the style, becoming glabrous towards the stigma; stipe c. $1.5 \mathrm{~mm}$ long, ovary globular, protruding, $1.5-2 \mathrm{~mm}$ long; pollen presenter lateral, broadly conical, c. $2 \mathrm{~mm}$ long with a central stigma. Fruits subglobular, pubescent, c. $12 \mathrm{~mm}$ long, $10 \mathrm{~mm}$ diameter; pericarp $1.4 \mathrm{~mm}$ thick; seeds narrowly peripterous c. $8 \mathrm{~mm}$ long, $4.5 \mathrm{~mm}$ wide, granulate to rugulose. Flowering period: September to November.

Distribution: Endemic to New South Wales, occurring in the Gungal-Kerrabee-Widden area of the Central Western Slopes, on the slopes of $M t$ Gundangaroo in the Central Tablelands, and perhaps in the Brogo River area of the South Coast. It usually grows in sheltered sites in dry sclerophyll woodland on the sides of steep gullies or in talus at the foot of sandstone cliffs. The nature of its habitat on the Brogo River is not known and further collections from this area would be desirable in order to verify the record.

SELECTEd Specimens: Central Western Slopes: Upper Hunter River, Stephenson NSW 92979, 12.1887; Gungal, Boorman NSW 92975, 9.1904 (NSW, BRI); Mount Dangar, c. west of Muswellbrook, Dornan 99, 10.1966 (NSW); Goulburn River, Murrumbo, Baker NSW 92973, 9.1895 (NSW, BRI); Cox's Gap, Murrumbo-Kerrabee, McKee 348, 10.1952 (NSW); Ridge S. of Emu Creek, 4 miles [6 km] SW. of Widden, Johnson NSW 92978 , 11.1955. Central Tablelands: Sir Johns Point, Mount Gundangaroo. 15 miles $[24 \mathrm{~km}]$ ENE. of Capertee, Constable $7225,10.1966$ (NSW). South Coast: Brogo River (c. $36^{\circ}$ $40^{\prime}$ S., $149^{\circ} 30^{\prime}$ E.), per J. Ward NSW 92981, 10.1947.

Grevillea johnsonii is closely related to $G$. longistyla Hook. but differs in its narrower more numerous pinnae, its shorter inflorescences and its pistil being sericeous to about the middle of the style. When cultivated in the Sydney district, the plant forms a handsome shrub which usually has a denser habit than its wild counterpart. 
The species is named in honour of Dr L.A.S. Johnson, whose perceptive insights into the Australian flora have added considerably to our understanding of many plant families.

\section{Grevillea rivulatis L. Johnson et D. McGillivray, sp. nov.}

Aff. G. acanthifoliae A. Cunn. sed foliis bipinnatipartitis, floribus paucioribus glabris differt.

Holotype: New South Wales: Central Tablelands: Carrington Falls, E.F. Constable NSW 92463, 1960. (Located in the National Herbarium of New South Wales, Sydney). Isotypes yet to be distributed.

Straggling to spreading shrub up to 2 metres high; young stems angular, with scattered appressed reddish hairs. Leaves partite, bipinnate or ternate, $3-6 \mathrm{~cm}$ long and of about the same width, rhachises straight or flexuose; pinnae up to 6 per leaf; ultimate segments linear to narrowly triangular, $1-3 \mathrm{~cm}$ long, $2 \mathrm{~mm}$ wide, pungently pointed. Inflorescence terminal, secund, c. $6 \mathrm{~cm}$ long, 12-30-flowered, displaced by a strongly developed proximal axillary branch; rhachis with scattered appressed hairs, soon becoming glabrous; floral bracts ovate, acuminate, with scattered hairs outside, somewhat keeled, deciduous when flower is c. equal in length to bract; pedicels $2 \mathrm{~mm}$ long, with scattered reddish hairs denser distally; torus oblique at c. $45^{\circ}$; perianth $14 \mathrm{~mm}$ long, broadest near the middle, $2 \mathrm{~mm}$ maximum diameter, totally glabrous; limb ovate, recurved, $2 \mathrm{~mm}$ long; gland conspicuous, semi-annular, uniformly $0.5 \mathrm{~mm}$ wide; pistil c. $25 \mathrm{~mm}$ long; stipe c. $2 \mathrm{~mm}$ long, glabrous ventrally, sericeous dorsally; ovary globose, $1 \mathrm{~mm}$ long, densely covered with straight ascending hairs; style glabrous, pollen presenter oblique, broadly conical, height c. $\frac{1}{3}$ width; stigma distally off-centre. Fruits obliquely ovate, $10 \mathrm{~mm}$ long, $5 \mathrm{~mm}$ wide, $4 \mathrm{~mm}$ across, light grey with irregular reddish brown stripes towards the dorsal surface; seeds semi-cylindrical to semi-ellipsoid, $7.5 \mathrm{~mm}$ long, $3 \mathrm{~mm}$ wide, faintly rugulose on the outer surface, flanged around the inner surface with a narrow "wing" c. 0.5 nmm wide.

Distribution: Restricted to the Carrington Falls area near Robertson on the Central Tablelands of New South Wales, where it occurs in sandy soil or alluvium in and near small streams.

Selected Specimens: Carrington Falls, Whaite 719, 21.12.1950 (NSW); Carrington Falls, Robertson, McBarron 15550, 23.8.1968 (NSW).

Grevillea rivularis resembles most closely Grevillea acanthifolia ssp. stenomera (F. Muell. ex Benth.) D. McGillivray (see below) but is readily distinguished from it and other members of Grevillea series Hebegynae Benth. by its bipinnatipartite leaves, glabrous perianth and conspicuously stipitate ovary.

In cultivation in the Royal Botanic Gardens, Sydney, it has grown to a dense shrub 2 metres high and c. 5 metres across within a few years. stat. nov,

Grevillea acanthifolia ssp. stenomera (F. Muell. ex Benth.) D. McGillivray,

BASIONYM: Grevillea acanthifolia lar. stenomera F. Muell. ex Benth., Fl. Austral. 5: 439 (1870).

Holotype: New South Wales: Head of Macleay River, C. Moore (K). Isotype: NSW 92462.

This plant strongly resembles the type subspecies in the structure of its flowers and fruits and in the pattern of leaf division, but is distinguished from 
it by its longer and narrower leaf segments (an exception being specimen NSW 92460 , from Bullock Creek near Point Lookout, which has leaves more closely resembling those of ssp. acanthifolia), shorter inflorescences and less conspicuous indumentum; differences which provide an insufficient basis for its separation at specific rank, but appropriate to its recognition as a geographically isolated subspecies.

$G$. acanthifolia ssp. stenomera occurs in moist situations on peaty to sandy soils in two areas within the Northern Tablelands of New South Wales; the Gibraltar Range, ENE. of Glen Innes, and in the vicinity of Point Lookout, E. of Armidale. Its southern counterpart, which is restricted to the higher parts of the Blue Mountains, W. of Sydney, occurs in similar habitats.

\section{Grevillea speciosa (Knight) D. McGillivray, comb, nov.}

Basionym: Lysanthe speciosa Knight, Proteeae: 118 (1809).

Holotype: Port Jackson, Paterson; ex Herb. Rudge (BM).

SYNonymy: Embothrium sericeum var. major Sm., Spec. Bot. New Holland 3: 27, t. 9 f. $5 \beta$ (1794), ' $\beta$ major'; Grevillea punicea $\mathrm{R}$. Br. in Trans. Linn. Soc. London 10: 169 (1810). TYPE: Port Jackson, in Herb. J.E. Smith (LINN, photograph seen). Brown did not include an asterisk beside the name $G$. punicea (as he did for new species published in Trans. Linn. Soc. London 10) and this is a further indication that the name $G$. punicea has Embothrium sericeum var. major as its replaced synonym.

This is an unfortunate change of name for a well-known species from the Sydney district, and it could have been avoided by the publication of a Grevillea $s p$. nov. with the same epithet. However, it is possible that the combination $G$. speciosa based on the Knight name has already been made, and its discovery would lead to more difficulties than the publication of this new combination will cause. There is also a possibility that an "armchair botanist" might publish this combination; and it is better for it to be done by a person with some knowledge of the group concerned.

Typification of the names Grevillea agrifolia $A$. Cunn. ex $R$. Br. and $G$. angulata $R, B r$.

LECTOTYPE (here designated) of $G$, agrifolia:

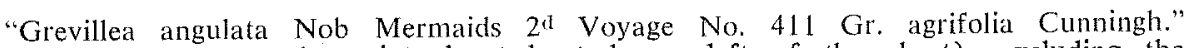
(label, in Robert Brown's script, located at lower left of the sheet); excluding the specimen at upper left labelled "Mermaids 3rd Voy. No. 12.". (BM).

LECTOTYPE (here designated) of $G$. angulata:

"G. ilicifolia Cunningh. Mermaids 1st Voyage No. 163 Sim's Island North Coast" (label on lower left of sheet), "Nova Hollandia Cunningham in King's 1st Voyage" (data on reverse side of sheet at top); excluding the fruiting specimen on the far left of the sheet. (BM).

These typifications have been made in order to avoid errors which could arise by confusion of the manuscript names with the validly published names associated with these taxa.

Grevillea agrifolia A. Cunn. ex R. Br., Suppl. Prodr. Prot. Nov.: 24 (1830). Grevillea agrifolia var. major Ewart et Ress in Proc. Roy. Soc. Victoria (n.s.) 24: 68 (1911), synon. nov.

Holotype: Western Australia: Mission station, Napier-Broome Bay, West Australia, G.F. Hill 22, December 1909 (10.xii.1909) (MEL). IsotYPE: MEL. 
Grevillea asplenifolia Knight and G. longifolia $R$. Br.

Grevillea aspleniifolia Knight, Proteeae; 120 (1809) [from the original]

Aspleniifolia; 1. G. folii 9-15 pollices longis, lineari-lanceolatis, integerrimus rareque dentatis: spicis simplicibus: stigmate peltato.

Asplenium-leaved Grevillia.

Many plants of this species were raised 3 years ago [1806] by $\mathrm{Mr}$ COLVILLE, who received the seeds from Port Jackson, but they were all lost in winter by too hardy treatments. Leaves 9 to 15 inches long, linear-lanceolate, quite entire or thinly dentated. Spikes simple. Stigma peltated.

NeOTyPe (here designated): NEW SOUth Wales: Port Jackson [on back of sheet], ex Herb. Banks. Labelled "Grevillea asplenifolia" by Dryander on front lower margin centre. (BM). See Plate I.

Synonym: Grevillea aspleniifolia R. Br, in Trans. Linn. Soc. London 10: 175 (1810), nomen illeg., non Knight (1809).

Holotype: as for the Neotype of $G$. aspleniifolia Knight. (In his description in the Prodromus, Brown referred to the original publication of the name, and also cited additional specimens, viz., 'G. Caley. v.s.'; see Plate II).

Grevillea aspleniifolia var. shepherdiana F. Muell. in Victorian Naturalist 10: 151 (Jan. 1894); Grevillea shepherdii Maiden et Betche, Census New South Wales Pl.: 59 nota (1916), nomen inval. [I.C.B.N. Art. 34].

Holotype: New South Wales: near Jervis Bay, Shepherd [Shephard'] 1893 (MEL 14280). [Mueller received the specimen (collected by Shepherd's son) following or with a letter from P.L.C. Shepherd dated 27th Dec., 1893; there is also another specimen collected by Shepherd dated 1894 (MEL 14279).]

Various author citations have been applied to $G$. aspleniifolia Knight, viz., R. Br., R. Br. ex Knight, R. Brown ex R. A. Salisbury [I.C.B.N. (1972) 299] but it is clear that Knight is the author who first validly published the name.

The original description prepared by Salisbury was possibly based on his recollections of the plants raised by Colville, and on observations made on the flowering specimen (Neotype) in the Banksian herbarium. He may have also seen the specimens collected by Caley, but it is improbable that these were a basis for any part of the protologue. Had the plants raised by Colville reached the flowering stage, it is likely that some reference to them would have appeared elsewhere, e.g. in Aiton's Hortus Kewensis, second edition (1810). If a flowering specimen of appropriate date, from Salisbury's herbarium, was, by some good chance, discovered, there would be little hesitation in regarding it as the Holotype. J.D. Hooker in Bot. Mag. 115: t. 7070 (1889) remarks:- "It is presumable that the descriptions published by Knight were drawn up in the Banksian Herbarium from materials prepared by Brown ....". It is a fact that some species were described from material in the Banksian herbarium, e.g., G. pteridifolia, $G$. parallela and $G$. glauca, all published by Knight. While material from Banks' herbarium was available to Brown, Robert Brown's own collections (and perhaps other specimens cited in Brown's Prodromus) were not, at that time, available to Banks' visitors, and it seems possible that the only material on which Salisbury could base a "description" of the inflorescence and stigma would be the specimen "New South Wales, Port Jackson" in Banks' herbarium. This is slightly supported by the fact that some leaves on this specimen are more than 9 inches long, whereas the leaves on the specimens from Caley are less than 9 inches long. The species is not included in Salisbury's manuscript notes and sketches housed in the library of the Botany Department, British Museum (Natural History). 


$$
\mathbb{W}
$$


Plate II

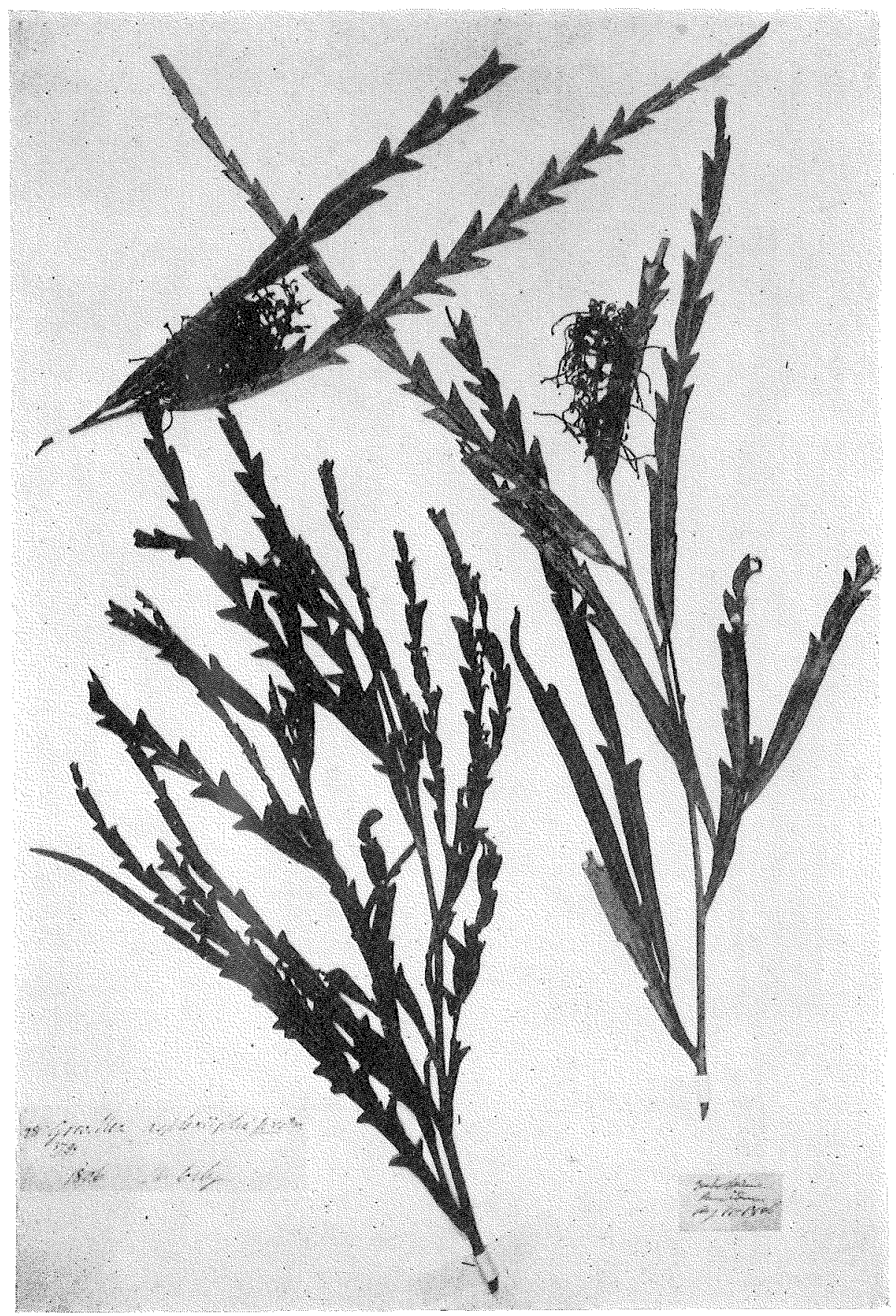

Grevillea aspleniifolia Knight. Caley's collection cited in R. Brown's Prodromus (see p. 25). 
[For references to Salisbury see McGillivray in Contr. New South Wales Natl. Herb. 4: 369-372 (1973) ].

Grevillea aspleniifolia Knight is the typus conservandus of the genus Grevillea R. Br. ex Knight.

It grows on the ridges and slopes of the catchments of the Nattai, Wollondilly, Kowmung, Coxs and Shoalhaven rivers (Central Coast, and isolated occurrences in Central and Southern Tablelands of New South Wales), usually occurring in woodland but tends to be in open rocky places, and never in close proximity to perennial streams. The latter are the habitats for $G$. longifolia from which it may be distinguished by its rounded, densely tomentose branches, its linear, entire or deeply divided leaves with a dense indumentum of curled hairs on the undersurface, and its rhomboid to obovate pollen presenter (broadly rhomboid in G. longifolia). G. aspleniifolia flowers from about July to November as does $G$. longifolia but unlike the latter it occasionally flowers also in late summer and autumn.

Selected Specimens: New South Wales: Central Coast: South bank of lower Cox's River between Popes Creek and Black Hollow Creek, Johnson NSW 92325, 18.12.1952; Burragorang Valley, 2 miles [ $3 \mathrm{~km}$ ] WSW. of Donohoes Flat, on Sheepwalk Road, Briggs 1121 \& Johnson, 23.2.1967 (NSW); Tonalli River to Byrnes Ck. Ridge, 2 miles [3 km] above landing, c. 18 miles [29 km] directly W. by N. from Picton, Mitchell 285, 17.11.1964 (NSW); near Nattai River, Stephenson NSW 92331, 12.1893; 6 miles [10 km] NW. of Hilltop, near junction of Nattai River and Rocky Waterhole Creek, Fairlie-Cuminghame NSW 96893, 19.2.1967. Central Tablelands: The Peak, Yerranderie, Boorman NSW 92328, 7.1915. Southern Tablelands: on ridges about $\frac{1}{2}$ mile $[0.8 \mathrm{~km}]$ SE. of Tolwong Mines road and along Dog Den Creek, c. $5 \mathrm{~km} \mathrm{S.} \mathrm{of} \mathrm{Bungonia} \mathrm{Caves,} \mathrm{T.} \mathrm{\&} \mathrm{J.} \mathrm{Whaite} \mathrm{3476,} 31.1 .1972$ (NSW).

Grevillea longifolia R. Br., Prodr., Suppl. Prot. Nov.: 22 (1830). G. aspleniifolia var. longifolia (R. Br.) Domin in Biblioth. Bot. 22 (891): 588 (1921).

Holotype: In the Brush close to the river a little above the Cataract, Caley July 1807 (BM); IsoTYPE: NSW. See plate III.

Misapplied Name: G. aspleniifolia auct. non Knight: Bentham, Fl. Austral. 5: 435 (1870), p. p.; F. Mueller, Syst. Census Austral. Pl.: 68 (1882); F. Mueller, Second Syst. Census: 117 (1889); Moore \& Betche, Handb. Fl. New South Wales: 238 (1893), p. p.; Maiden \& Betche, Census New South Wales Pl.: 59 (1916): Beadle, Evans \& Carolin, Handb. Vasc. Pl. Sydney Distr.: 189 (1963), p. p. Both species are clearly presented in Beadle, Evans \& Carolin, Fl. Sydney Region: 222 (1972).

Grevillea longifolia occurs in forest and woodland, usually beside streams, in the Lawson to Springwood area of the Blue Mountains, Georges River, Woronora River and as far south as Appin and the lower Cataract River. The record of Leichhardt's collection from Moreton Bay (F. Mueller Fragm. 6: 212) was from a cultivated specimen in Mrs Bowman's garden, a locality cited for some other species not indigenous to Queensland. The Bowman's property was at Ravensworth between Singleton and Muswellbrook in New South Wales. Leichhardt called there in April 1843 on his way to Moreton Bay.

The species differs from $G$. aspleniifolia in its angular sericeous branchlets, its serrate, rarely entire, linear to vary narrowly ovate-elliptical leaves with a sericeous indumentum on the undersurface, and its broadly rhomboid pollen presenter.

The plant is quite widely cultivated, usually under the name $G$. aspleniifolia. In London at Christmas time one may purchase bunches of its decorative foliage taken from cultivated plants grown in the south of England and in France. 
Plate III

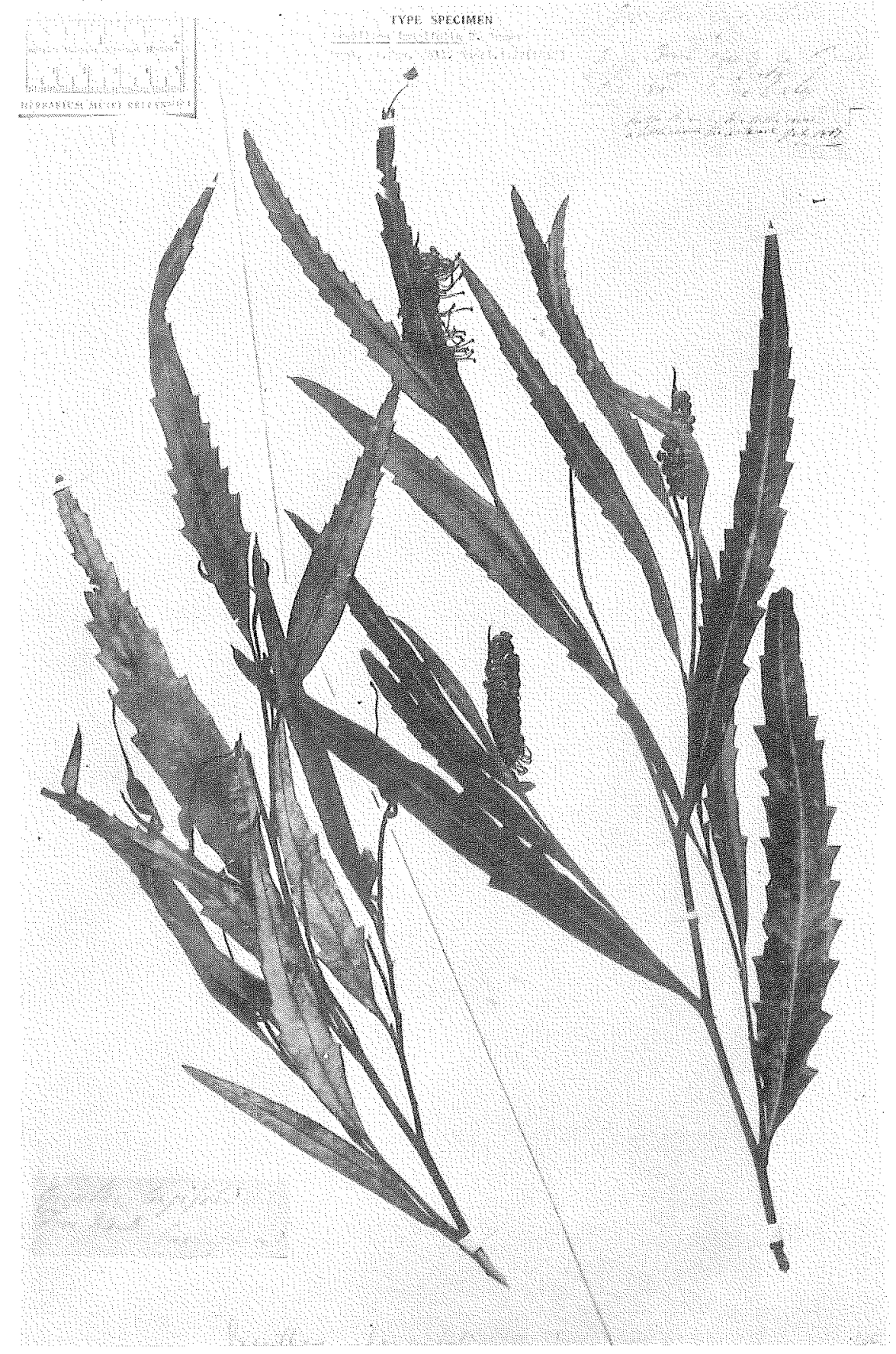

Holotype: Grevillea longifolia R. Br. (see p. 26). 
Selected Specimens: New South Wales: Central Coast: Parramatta River, near Burwood, Boorman NSW 92342, 8.1898; Lawson, Hamilton NSW 92340, 10.1898; Heathcote, Woronora River, Hamilton NSW 92347, 10.1915; Georges River, Kentlyn, McBarron 13169, 1.10.1966 (NSW); Woolwash, E. of Campbelltown, Ford NSW 92352, 8.1950; Kings Fall (near Appin), Cunningham, 1818 (BM, NSW); Broughton Pass, lower Cataract River, Johnson NSW 92354, 5.1951.

Grevillea biformis Meisn.; the correct name for the species named $G$. stenocarpa F. Muell. ex Benth.

When publishing the name $G$. stenocarpa Bentham explained that:-

"In some herbaria, Drummond's specimens n. 265 (the type of G. biformis Meisn.) are associated with others without flowers of $G$. integrifolia, and had evidently been so transmitted by Drummond, in other cases the corresponding leafy specimens had been correctly sent with the following ones of $G$. integrifolia. I have therefore been unable to retain Meissner's specific name founded upon the supposed dimotphous foliage."

Grevillea biformis does have dimorphous foliage, i.e. obovate juvenile leaves, but the identity of the vegetative type specimen from Drummond's 3rd Collection no. 265 has yet to be definitely determined.

Grevillea biformis Meisn. in Lehmann, P1. Preiss. 2: 258 (1848).

LECTOTYPE (here designated): Drummond 265, packet at centre right of sheet of G. biformis from the Meisner herbarium, housed in the herbarium of the New York Botanical Garden (NY).

SYNONYM: Grevillea stenocarpa F. Muell. ex Benth., Fl. Austral. 5: 485 (1870), nomen illeg.

Grevillea cirsiifolia Meisn.; explanation for an erroneous record.

Moore \& Betche, Handb. Fl. New South Wales: 238 (1893) record this species from "Summit of Mount Lindsay" (Mt Lindesay on the border between New South Wales and Queensland). This reference was followed by F.M. Bailey, Queensland Fl. 4: 1337 (1901), "Summit of Mount Lindsay C. Moore", and the species was recorded in Bailey's Comprehensive Catalogue: 452 (1913). Maiden \& Betche, Census New South Wales Pl.: 59 nota (1916) comment:-

" $G$. cirsiifolia is recorded by Mueller and Bentham from Western Australia only. It was admitted into the 'Handbook of the Flora of New South Wales', on the evidence of Mr F.M. Bailey, who records it from the summit of Mt Lindsay, a mount on the border of New South Wales and Queensland, and a most unlikely. locality for a Western Australian plant."

Whatever the truth of the error's origin, it is clear that the source of the mistake about this endemic Western Australian species is a locality of the same name in that State; e.g. see the specimen of $G$. cirsiifolia:-

Western Australia: Mount Lindsay (Mt Lindesay, SW. of Mt Barker and WNW. of Albany), W. Webb, 1882 (MEL).

\section{Grevillea heliosperma $R, B r$, and G. decurrens Ewart.}

Grevillea heliosperma occurs discontinuously from north-western Australia to north-western Queensland in open forest or woodland on sandy soils derived from quartzite or sandstone and southward on truncated lateritic soils. It flowers from (April) May to August (October) and mature fruiting specimens have been 
collected rarely. The lower margins of the pinnae are not decurrent as in $G$. decurrens and the apices of the pinnae are usually acute.

$G$. decurrens is of more restricted distribution, occurring only in the Northern Territory from Melville Island and the Darwin area south to c. $16^{\circ} \mathrm{S}$. at lat. $132^{\circ} \mathrm{E}$, and east to about Mainoru, $14^{\circ} \mathrm{S}$., $134^{\circ} \mathrm{E}$. It occurs in forest or woodland on sandy to gravelly soils. The species flowers from (December) January to February (June) and a number of fruiting specimens have been collected (June to October). The lower margins of the pinnae are decurrent and their apices are usually obtuse. Mid-veins of the pinnae are more conspicuous than those of $G$. heliosperma.

Grevillea oleoides Sieber ex Schultes et Schultes $f$. and G. dimorpha F. Muell.

Vegetatively the species may be distinguished by the indumentum, e.g. hairs scraped from the underside of the leaves of $G$. oleoides have a smooth feel when rubbed between the fingers whereas those of $G$. dimorpha have a crisp feel; microscopic examination of the hairs show that those of $G$. dimorpha are markedly broader than those of $G$. oleoides. Close attention to the nature of the indumentum yields much useful diagnostic information in the Proteaceae generally.

The inflorescences of $G$. oleoides have c. 12-16 flowers with the pistils 30 $\mathrm{mm}$ or more in length; in $G$. dimorpha there are c. 8-12 flowers per inflorescence and the length of the pistils is $22-28 \mathrm{~mm}$.

$G$. dimorpha is confined to SW. Victoria and $G$. oleoides restricted to the Central Coast and Blue Mountains of New South Wales.

\section{Grevillea oleoides Sieber ex Schultes et Schultes $f$.}

Synonym: G. seymouriae Sweet ex Meisn. in DC. Prodr. 14: 345 (1856). LectotyPE (here designated): Georges R., McArthur n. 214; in a packet on the upper right on the sheet of $G$. seymouriae in the Meisner Herbarium housed in the herbarium of the New York Botanical Garden (NY).

Grevillea glabella $R$. $B r$, reinstated

G. glabella R. Br., Prodr. Suppl. Prot. Nov.: 20 (1830).

Lectotype (here designated): "Oxley's 1st Expedition" (R. Brown script); specimen at upper left of sheet bearing also specimens from Fraser (BM). See plate IV.

Bentham, Fl. Austral. 5: 445 (1870) did not consider the species to be worthy of full description but mentioned correctly that "it is very near both to $G$. ericifolia and G. rosmarinifolia." $G$. ericifolia, whatever the status of the taxon, is more closely related to $G$. laniger $a$ which has a villous ovary, and $G$. glabella is more closely related to $G$. rosmarinifolia, with which it shares the diagnostically important characteristic of pistils glabrous except for a patch of hairs at the base of the ovary.

$G$. glabella is characterized by a much branched habit with relatively stiff branches, and slender linear leaves $1-2 \mathrm{~cm}$ long and less than $1 \mathrm{~mm}$ wide.

In New South Wales it is recorded from the Central Western Slopes and Western Plains in the region Barellan-Taleeban-Rankins Springs-Merriwagga, and from Victoria in the Little Desert region. 
Plate IV

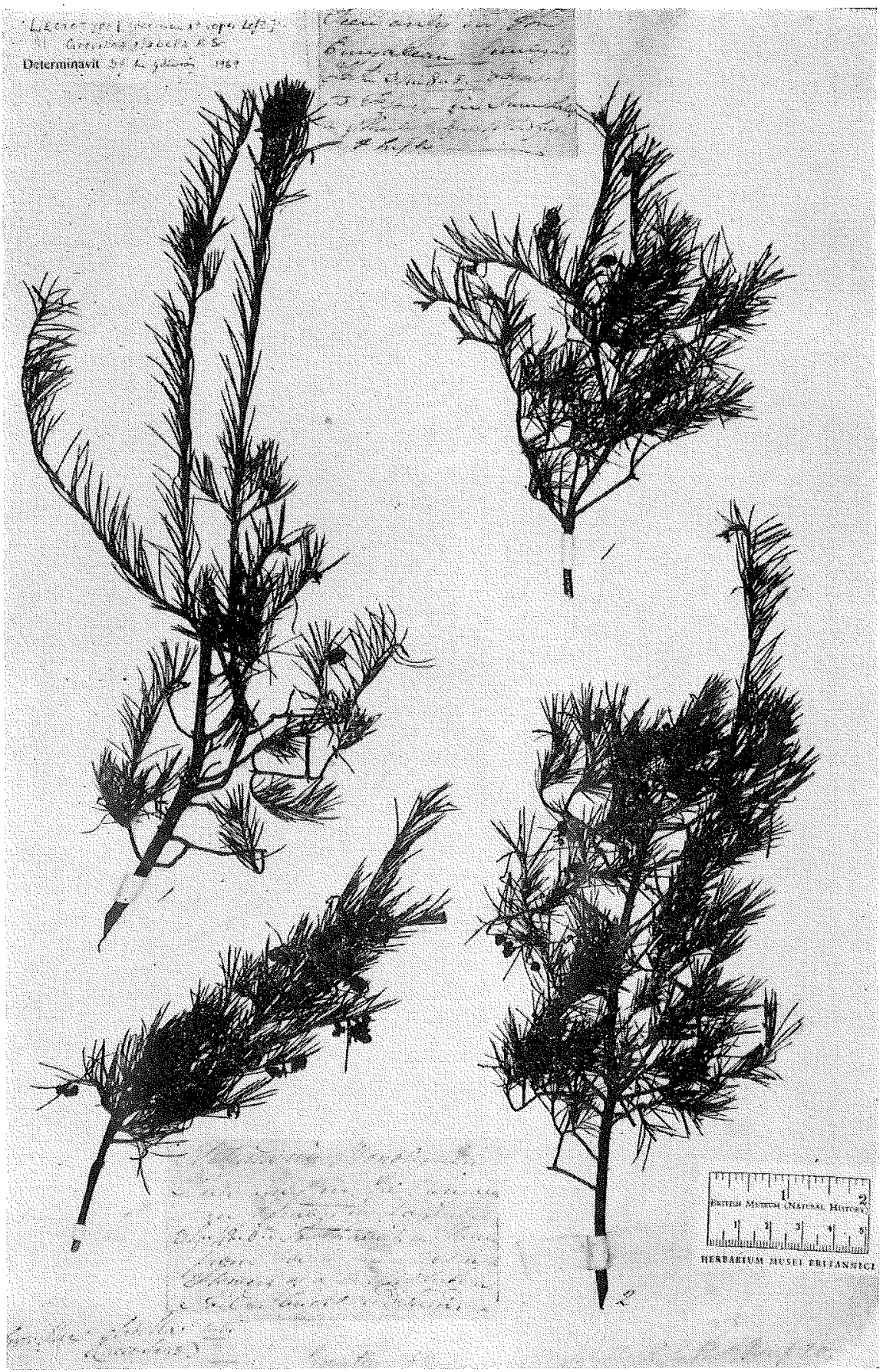

LECTOTYPE: Grevillea glabella $\mathrm{R}$. Br. The label in the lower left hand corner in R. Brown's script relates to the Lectotype. The other labels bear Charles Fraser's script (see p. 28). 
Within the native plants nursery trade it has been known as "Rankinsi".

Grevillea cumeata (Endl.) Druce, nomen nudum and G. glabrata (Lindl.) Meisn.

The "basionym" for the name G. cuneata is Manglesia cuneata Endl., Nov. Stirp. Dec.: 25 (1839), here quoted:- (following on the description of the new genus Manglesia)

"Genus, ad quod praeter species novas infra describendas $[M$. tridentifera and $M$. vestita], et Manglesiam cuneatam Endl. (quae Grevillea Manglesii Hortul.), versimiliter omnes Grevillea sectionis Conogyne R. Brown . . " continuing in discussion of relationships of the new genus; this discussion cannot be regarded as a description of $M$. cuneata.

Heynhold, Nomencl. Bot. 1: 368 (1840) published the nomen nudum "Grevillea Manglesii Mack. C." a reference to the catalogue of nurserymen C. Mackay. I have tried to locate a copy of this catalogue from the libraries believed to be most likely to hold it, but have not found any of Mackay's catalogues; the period of issue of the one cited by Heynhold would be the latter part of the 1830 's.

I am not anxious to change the currently correct name Grevillea glabrata (Lindl.) Meisn. (Basionym: Manglesia glabrata; Type: CGE) but I wish to see the Mackay catalogue for the names of other Australian plants it contains and because it has been cited by authors other than Heynhold.

Grevillea inconspicua Diels; G. brachyclada W. V. Fitzg. synon. nov.

Grevillea inconspicua Diels in Bot. Jahrb., Syst. 35: 153 (1904); Gardner, Enum. Pl. Austral. Occid.: 30 (1930); Blackall \& Grieve, Western Austral. Wildflowers 1: 106 incl. fig. (1954); Beard, Descr. Cat. West Austral. Pl.: 21 (1965), ed. 2: 39 (1970). Holotype: Western Australia: Hab. in distr. Austin pr. Cue in rubestribus lutosis fruticosis flor. m. Jun. et. Jul., Diels 3277 (B).

SYNONYM: Grevillea brachyclada W.V. Fitzg. in J. Western Australia Nat. Hist. Soc. 2 : 30 (1905); Gardner, Enum. P1. Austral. Occid.: 30 (1930); Blackall \& Grieve, Western Austral. Wildflowers 1: 112 incl. fig. (1954). Holotype: WESTERn Australia: Greenough River, C.R.P. Andrew' 7.1903 (NSW).

\section{Grevillea parallela Knight: new synonyms}

Grevillea parallela Knight, Proteeae: 121 (1809).

G. ceratophylla R. Br. in Trans. Linn. Soc. London 10: 177 (1810); G. refracta var. ceratophylla ( $R$. Br.) Benth., Fl. Austral. 5: (1870), synon. nov.

LECTOTYPE (here designated): of G. ceratophylla: "Carpentaria Islands Jany 20 1803" (Morgan Island, c. $13^{\circ}$ S., $136^{\circ}$ E.), R. Brown; excluding the simple-leaved specimen (BM).

G. heteroneura W.V. Fitzg. in J. \& Proc. Roy. Soc. Western Australia 3: 132 (1918), synon. nov.

Lectotype (here designated) Western Australm: Table Top Mountain (c. $16^{\circ} 30^{\prime} \mathrm{S}$, $125^{\circ} 10^{\prime}$ E.), W.Y. Fitzgerald 9.1905 (NSW).

The name G. pityophylla $F$. Muell. replaces G. blackallii C. A. Gardn.

Grevillea pityophylla F. Muell., Fragm. 6: 208 (1868); Bentham, Fl. Austral. 5: 433 (1870). Holotype: Western Australia: W.A. Dr. [J. Drummond]. Folia flores muto majora quam ea Gr. pinifoliae (MEL 52534). 
Synonym: Grevillea blackallii C.A. Gardn. in J. \& Proc. Roy. Soc. Western Australia 22: 121 (1936), synon, nov.; Blackall \& Grieve, Western Austral. Wildflowers 1: 108 incl. fig. (1954); Beard, Descr. Cat. West Austral. Pl.: 21 (1965), ed. 2; 38 (1970). LectoTYPE (here designated): Western Australia: Payne's Find, shrub 12-18 ins high, flrs scarlet.

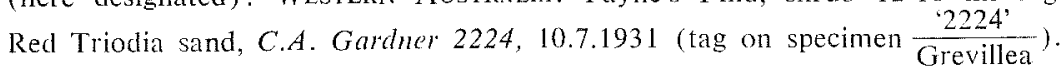

The species was described by Mueller from a specimen in Drummond's personal herbarium which was acquired by Mueller about 1865 and is now in the National Herbarium of Victoria (MEL). Duplicates of the type are absent from a number of other herbaria where Drummond's collections are well-represented.

Bentham, op. cit. remarked that this species appeared to be the same as Grevillea eriostachya Lind1., a mistake partly attributable to the fragmentary nature of the specimen.

Grevillea pityophylla appears to be restricted to the Austin district and in the vicinity of Lat. $29^{\circ} 30^{\prime} \mathrm{S}$., Long. $117^{\circ} 30^{\prime} \mathrm{E}$. Its main flowering period is July-August, but it has been found in flower as late as October.

Rediscovery of Grevillea rosmarinifolia A. Cunn. sens, orig.

Allan Cunningham collected this species in 1822 near the site of the military depot located by the Coxs River on the (old) road to Bathurst. It was consequently introduced into cultivation in England, and was figured by Sweet, F1. Australasica: t. 30 (1828) and by J.D. Hooker in Bot. Mag. 98: t. 5971 (1872). Grevillea rosmarinifolia was originally described by Cunningham in Field, Geogr. Mem. New South Wales: 328 (1825). No record of collections since 1822 is known, although several searches have been made for it in recent years, but "forms" of the species are known from the southern tablelands of New South Wales and in Victoria.

In August 1969 the author observed a specimen of the type form of $G$. rosmarinifolia growing outdoors, beside a building in the Edinburgh Botanic Garden. Cuttings from the plant were sent to the Royal Botanic Gardens, Sydney, and specimens have been established in a number of gardens and some nurseries in New South Wales and Victoria. It is distinguished from other forms of the species by its longer, broader leaves, c. $2.5-4 \mathrm{~cm}$ long and 2-3 $\mathrm{mm}$ wide.

\section{Grevillea singuliflora $F$. Muell. and G. shiressii Blakely}

When Blakely described G. shiressii in Proc. Linn. Soc. New South Wales 50: 383 (1925), he placed it in the section Lissostylis and remarked that it appeared to have no close affinities with any eastern Australian species. However he had not seen flowering specimens of $G$. singuliffora which in its flowers is strikingly similar to $G$. shiressii. The latter has narrowly ovate, undulate leaves $8-16 \mathrm{~cm}$ long, $2-4 \mathrm{~cm}$ wide, and is confined to the sides of streams in a very small area near Wondabyne on the Central Coast of New South Wales. G. singuliflora has ovate, undulate leaves $1-2 \mathrm{~cm}$ long; it occurs in scattered localities in southcastern Queensland.

\section{Hakea eyreama ( $S$. Moore) D. McGillivay, comb. nov.}

Basionym: Grevillea eyreana S. Moore in J. Linn. Soc. Bot. 45: 210 (1920). Holotype: South Australia: A tree Lat 27.30 on sand hills, Capt. Sturt (BM).

SyNONYMY: Hakea intermedia Ewart et Davies, Fl. N. Territory: 85, 86, Pl. X, figs. 1-4 (1917), non Hook. (1841), nomen illeg.; Hakea divaricata L. Johnson, Contr. New South Wales Natl. Herb. 3: 93 (1962), based on the former name. SYNTYPES: MEL, not seen. 


\section{Hakea pulvinifera L. Johnson - is it extinct? (See Plate V.)}

This localized endemic species, first collected in 1949, is possibly now extinct. It was known only from a steep barren slope $1.5 \mathrm{~km}$ SSE. of the wall of Keepit Dam, c. $30 \mathrm{~km}$ ENE. of Gunnedah, New South Wales. The latest collection was made in April 1966 when this locality was visited by L.A.S. Johnson who had described the species in 1962. He noted the following details:- ' 1 mile [1.5 km] SSE. of Keepit Dam. Notes: Shrubs or stunted treelets to $4 \mathrm{~m}$, often less, bark more or less corky, thick, more or less tesselated. No old fruits found. Very localised to the crest and $W$. side of a very dry, barren conglomerate hillside, with scattered Callitris columellaris and Alstonia constricta.'

In April 1971, R.G. Coveny, the Botanical Collector for the Royal Botanic Gardens, Sydney, and I searched the type locality but could find no trace of this species, not even old wood fragments. The slope had been partly cleared and a portion of the top of the ridge had been cleared and flattened to form a car parking area. It is possible, though unlikely, that the species may occur in other places.

\section{Isopogon mmoraifolius $D$. McGillivray, sp. nov.}

Aff. I. dawsonii R.T. Baker sed lobis foliorum brevibus, rhachidibus seu petiolis latis planis, squamis strobilorum acutioribus differt.

Holotype: New South Wales: North Coast: Bald Knob, Angourie, $6 \mathrm{~km}$ S. of Yamba, D.J. McGillivray 2705 and J. de S. Disney, 27.ix.1967 (located in the National Herbarium of New South Wales). IsOTYPES: BRI, CANB, K, PERTH, RSA, yet to be distributed.

Shrub 40-80 $\mathrm{cm}$ high, branchlets pubescent. Leaves once or twice partite or sometimes undivided, overall size $4-10 \mathrm{~cm}$ long, $(0.2-) 1-3 \mathrm{~cm}$ wide, broadest across or near the apex; ultimate lobes linear to triangular, usually curved towards the leaf axis, $1-15 \mathrm{~mm}$ long, $0.7-1.5 \mathrm{~mm}$ wide; upper part of the undivided portion of the rhachis flat to concave; undivided part commonly c. twice the length of the divided part of the leaf. Flowering cones sessile, subtended by sparingly divided or undivided leaves, cones (without the perianths) $10-14 \mathrm{~mm}$ long, $15-18 \mathrm{~mm}$ in diameter; receptacle ovoid; outer cone scales broadly ovate to ovate, $3-5 \mathrm{~mm}$ long, $3-4 \mathrm{~mm}$ wide, sericeous outside with glabrous apex; medial to apical cone scales elliptical to obovate $6-9 \mathrm{~mm}$ long, $2-2.5 \mathrm{~mm}$ wide, woolly on the outside to just above the middle, tapering to a narrowly acute, glabrous apex c. $2-3 \mathrm{~mm}$ long. Perianth creamy-yellow, $17-20 \mathrm{~mm}$ long at anthesis, glabrous for $5-8 \mathrm{~mm}$ from the base, soon becoming densely villous for the remainder; pollen presenter fusiform, bright yellowish-orange when fresh, $4 \mathrm{~mm}$ long, $0.5 \mathrm{~mm}$ in diameter with a medial constriction, the lower $2.5 \mathrm{~mm}$ of the presenter densely covered with short strap-like hairs and papillae. Fruiting cones $15-18 \mathrm{~mm}$ long, $16-22 \mathrm{~mm}$ in diameter, fruits ovoid to ellipsoid, somewhat trigonous, $2.5-3 \mathrm{~mm}$ long, $1-1.5 \mathrm{~mm}$ across, covered with fine, white, spreading hairs c. $6 \mathrm{~mm}$ long.

Distribution: Endemic to the North Coast of New South Wales, growing in open heath or on the edge of woodland on clay loam or (?) sand from near Coaldale (c. $32 \mathrm{~km}$ directly NNW. of Grafton) and on the coast E. of Grafton from Angourie (c. $6 \mathrm{~km} \mathrm{~S}$. of Yamba) to Minnie Water (c. $32 \mathrm{~km}$ directly ESE. of Grafton).

SELECTED SPECIMENS: North Coast: 8 miles [13 km] SSE. of Coaldale by road, $R$. Coveny 1881, S. Clark \& J. Pickard, 30.7 .1969 (NSW); The Bald Knob, Angourie, c. 4 miles [6 km] S. of Yamba, D.J. McGillivray 2155, 1.7.1966 (NSW); Minnie Water, N. of Wooli, D.J. McGillivray 2719 \& J. de S. Disney, 28.9.1967 (NSW).

Apparently the species was overlooked until 1966, probably because of its restricted range and its superficial resemblance to Isopogon anemonifolius (Salisb.) Knight which is common in the coastal portion of its range as far north as Smoky Cape (c. $100 \mathrm{~km} \mathrm{~S}$. of the range for $I$. mnoraifolius). In $I$. anemonifolius and $I$. 
Plate V
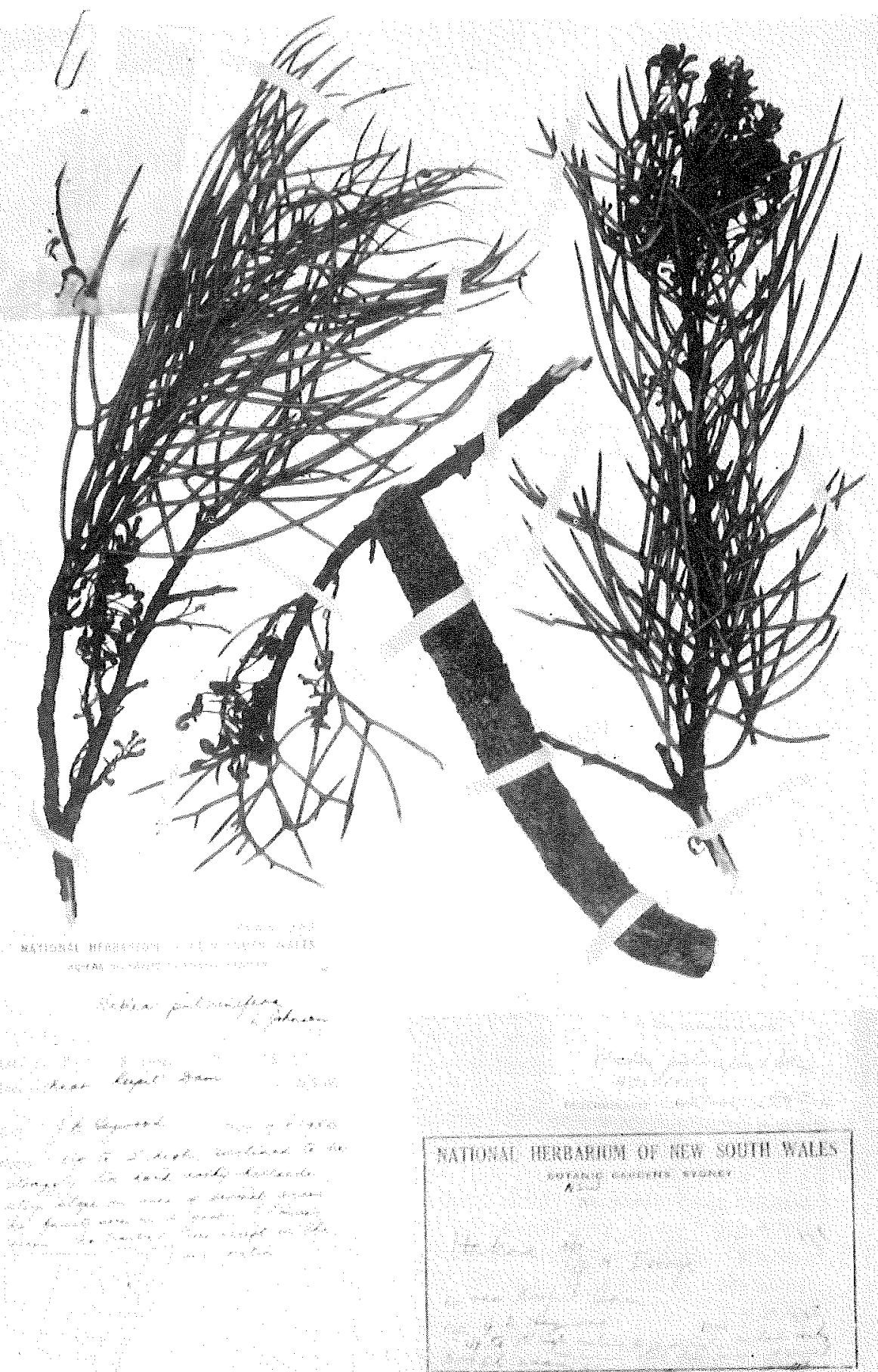

Holotype: Hakea pulvinifera L. Johnson (see p. 31). 
petiolaris A. Cunn. ex R. Br. (which extends into the Coaldale area) the perianths are glabrous except for a terminal tuft of hairs. I. mnoraifolius is closely related to I. dawsonii R. T. Baker from which it differs in several respects, most noticeably in its shorter leaf lobes, its broader and flatter leaf-rhachis (petiole) and its fewer, more acute cone scales. The shape of the leaves is reminiscent of the menorah, the Jewish candelabra, hence the specific epithet (which is pronounced mnoräifolius ) .

Isopogon prostratus D. McGillivray, nom. et siat. nov.

RePlaced Synonym: Isopogon anemonifolius var, tenuifolius F. Muell. ex Benth., Fl. Austral. 5: 347 (1870). Holotype: New South Wales: Twofold Bay, F. Mueller (K). Isotypes: Twofold Bay, F. Mueller, 10.1860 (MEL, NSW).

Distribution: The species occurs on the Central Tablelands (S. from Clarence), Southern Tablelands and South Coast of New South Wales. It is rare in Victoria and known only from "scrubby heaths along the railway line between Providence Ponds $\mathrm{Ck}$ and Fernbank Station, East Gippsland" [fide J.H. Willis, Handb. Pl. Victoria 2: 37 (1973)]. I have also seen the Victorian collections of this plant.

The species differs from 1 . anemonifolius in several respects, e.g. in its prostrate habit, more slender leaf segments and slightly more conspicuous terminal tuft of hairs on the limb of the perianth.

Petrophile pulchella (Schrad.) $R$. Br. - a correct name

The name $P$. pulchella has priority over the name $P$. fucifolia (Salisb.) Knight; their basionyms under the generic name Protea were published in March 1796 and November-December 1796 respectively, the former by Schrader in Sertum Hannoveranum 2: 15, t. 7 , the latter by Salisbury in his Prodromus: 48 (1796).

\section{CORRECTION}

In a paper about R.A. Salisbury [Contr. New South Wales Natl. Herb. 4: 369 (1973)] I suggested that Leucospermum rodolentum (Knight) Rourke is a superfluous name. In this I was quite mistaken and the correct name is that as published by Dr Rourke in J. S. African Bot. 35: 325 (1969).

\section{ACKNOWLEDGEMENTS}

I wish to thank Dr L.A.S. Johnson for his generous assistance on a number of matters relating to this paper and to my training as a taxonomist. $\mathrm{Mr} N$. Byrnes kindly provided much useful information about the species in the Northern Territory and Mr J.R. Maconochie made many valuable collections of Proteaceae from northern Australia, from which he sent duplicates to Sydney (NSW).

The Directors of herbaria in Melbourne and Brisbane assisted me during various visits to their institutions and to them I am very grateful. I also wish to thank the Keeper, Botany Department, British Museum (Natural History) for providing facilities for me to study the collections and manuscripts of Robert Brown, and the Trustees of the British Museum (Natural History) for permission to reproduce the photographs in plates I-IV. 